\title{
DEMOGRAPHIC TRANSITION AND PUBLIC POLICY: CHILE 1850-2000
}

TRANSICION DEMOGRAFICA Y POLITICA PUBLICA:

CHILE 1850-2000

\section{PABLO VILLALOBOS DINTRANS*}

Independiente

\begin{abstract}
Chile has experienced tremendous changes over the past centuries. Notwithstanding the importance of many of these transformations, the demographic change has been crucial, given its influence on the whole Chilean society.

This paper inquires into the effects of the Chilean demographic transition on the fiscal policies implemented by the government throughout a 150 years period. The results suggest a correlation between demographic variables and fiscal expenditure on different goods. Particularly, the estimations find a positive impact of a younger population on educational expenditure and negative effects of the share of adult population on fiscal expenditures.
\end{abstract}

Keywords: Demographic transition, fiscal policy, publicly provided goods.

JEL Classification: $H 4, H 5, J 1, N 3, N 4$.

\section{Resumen}

Chile ha experimentado enormes cambios durante los últimos 200 años. A pesar de la importancia de muchas de estas transformaciones, el cambio demográfico ha sido crucial, dada su influencia en todos los aspectos de la sociedad chilena.

* I am grateful to Robert Margo for his guidance and useful comments in the development of this work. I am also indebted to Victor Salinas who provided most of the interesting historical references as well as many valuable comments. Finally, I like to thanks Carla Castillo, Claudio Villalobos, Zaid Derweesh, and an anonymous referee for their comments to previous versions of this paper. Any remaining errors are responsibility of the author. 


\begin{abstract}
Este trabajo investiga los efectos de la transición demográfica chilena en las políticas fiscales implementadas por los gobiernos a lo largo de un periodo de 150 años. Los resultados sugieren una correlación entre variables demográficas y el gasto fiscal en diferentes bienes. En particular, las estimaciones encuentran un resultado positivo de una población más joven sobre el gasto en educación y efectos negativos del porcentaje de población adulta sobre el gasto fiscal.
\end{abstract}

Palabras clave: Transición demográfica, política fiscal, bienes de provisión pública.

Clasificación JEL: $H 4, H 5, J 1, N 3, N 4$.

\title{
1. INTRODUCTION
}

Chile has experienced tremendous changes over the past centuries. Notwithstanding the importance of many of these transformations, the demographic change has been crucial, particularly because of its influence on the whole Chilean society.

The aim of this paper is to present the main features of the demographic transition in Chile and their effects on the public policies followed by the governments throughout the country's history. The analysis is conducted using a framework where the government acts as complement of the private sector in the provision of some goods. As result, the link between demographic changes, specifically the change in the age distribution in the population, and fiscal expenditure is determined by a combination of different needs arising from diverse segments of the population, and by the ability of the productive sector to respond to these demands.

The results show the existence of a positive relationship between population and fiscal expenditure, a negative effect of the adult population in public expenditure and a positive impact of spending in specific goods when the population demanding the good is relatively more abundant.

The presentation is organized as follows. Section 2 presents the main features of the Chilean demographic transition over a 150 years period (1850-2000). Section 3 establishes the relationship between demographic and economic characteristics and the way in which demographic changes impact fiscal policy. The empirical methodology used to measure the effects of the demographic change on the public policy is presented in Section 4, while the description of the data and the results are shown in Section 5. The final section is reserved to the conclusions and sketches extensions for further research.

\section{THE CHILEAN DEMOGRAPHIC TRANSITION}

Demographic change is a widespread phenomenon around the world, but it has had different timing in different countries; while in Europe it started around 
1800 , in developing countries began at the beginning of the $20^{\text {th }}$ century (Lee, 2003). The evolution of the main demographic variables in Chile is presented in Figure 1. The data covers a 150 years period of Chilean history. The chart shows the magnitude of the demographic changes which might have affected the society in different epochs. It shows three marked periods of population growth rate: first, a period between 1850 and 1910, when the population growth declined; secondly, an episode with a marked increase between 1910 and 1962; and finally, period of decrease in the growth of the population since the mid-1960s until 2000 (with a reverse during the 1980 decade).

\section{FIGURE 1}

POPULATION, BIRTH AND DEATH RATES, 1850-2000

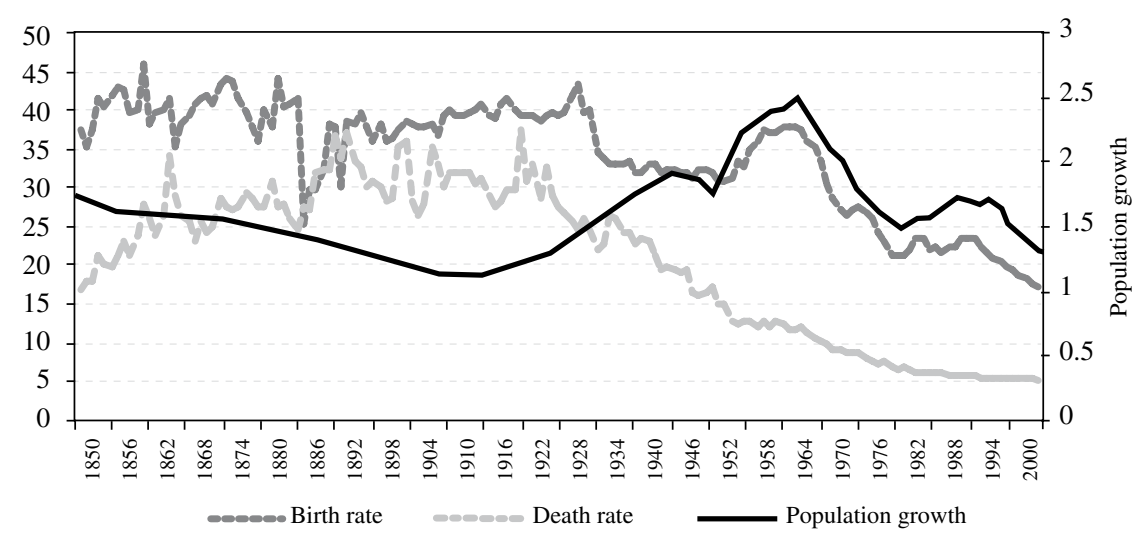

Source: Author's elaboration based on Díaz, Lüders and Wagner (2010).

The pattern depicted by the data follows the usual phases of a demographic transition (Lee, 2003; Ito and Rose, 2010). In the first stage both fertility and mortality rates are high. During the second phase, population rises driven by the reduction in mortality rates. In the third phase, fertility begins to fall, producing a decrease in the population rate. The behavior of the fertility and mortality rates determine not only the population growth, but the distribution of ages in the population in each period.

First stage (1850-1910): This stage is characterized by a high and constant birth rate (around 40 live births for each 1,000 inhabitants), except for a period with a sharp decrease in 1885 . After this date, the birth rate rises again, reaching a level slightly lower than the one showed in the previous decades. On the other hand, the death rate 
followed an increasing path until 1864, where it reached a peak of 34 deaths for each 1,000 inhabitants $(34 / 1,000)$. The death rate shows to be relatively stable (around $28 / 1,000$ ) in the following years, except for a turbulent period in the late 1890s, where the political situation and the posterior Civil War increased the death rate to approximately $37 / 1,000$ in 1890 and 1892 . Both effects explain the sustained decrease in population growth until the early 1910s.

Documents of the time highlight the situation of the Chilean mortality during the last years of the $19^{\text {th }}$ century. Murillo (1896) presents disturbing numbers, emphasizing the high rates of urban mortality as a social and economic problem. According to the author, the three main Chilean cities -Santiago, Valparaíso and Concepción-presented a number of deaths proportionally three times higher than other big cities in more developed countries. These numbers were comparable to the situation exhibited by African or Asiatic cities. The main factor behind these deaths was the high infant death, and the prevalence of infectious diseases. Other variables, such as a cholera epidemic in 1887, explain the increase of mortality rates during the last decade of the $19^{\text {th }}$ century (Murillo, 1896; Laval, 2003a). The Civil War of 1891 is another event to take into account. It was a major incident in Chilean history causing thousands of deaths (San Francisco, 2007) and influencing death and birth rates.

In this stage, the behavior of the population rate during the first years (18501900 ) is mainly explained by variations in the death rate. After 1900, the death rate stopped its increasing trend and showed fluctuations around 32/1,000 deceases. In this later period, the decrease in the population growth is explained by the lower level of the birth rate with respect to the previous period (37.7/1,000 versus $40.4 / 1,000$ in 1850-1900).

Second Stage (1910-1962): This stage resembles the typical start of the demographic transition, i.e. a rise in the population driven by a sharp decrease in mortality. Between 1910 and 1930 the birth rate grew at a slightly increasing rate, reaching a peak of more than 43 for each 1,000 births.

Death rate continued to be high throughout the decade of 1910 , reaching a peak during the period comprised between 1915 and 1920. A possible explanation is the epidemic outbreak originated in 1918. The emergence of a series of "mysterious deaths" raised the medical debate, which concluded that during this period there were not one, but two epidemics in Chile (Laval, 2003b). In spite of this, the death rate began to decline systematically in 1924, falling abruptly from almost 33/1,000 deceases to 22/1,000 deceases in less than 10 years (1923 to 1931). After a small reversal in the decreasing tendency during the early 1930s, the rate fell constantly, reaching 12 deceases per 1,000 persons in 1960. This process is mainly explained by the dramatic decrease in infant and neonatal mortality rates experienced since the beginning of the $20^{\text {th }}$ century (see Figure 2 ). This decline was mainly driven by an increase in the professional assistance of the births: while in 1930, 88\% of the births occurred in particular houses, by 1950 the births registered in hospitals increased to 37\%, and in 1990 reached 99.5\% (Aguila and Muñoz, 1997). 


\section{FIGURE 2}

MORTALITY RATES, 1900-2000

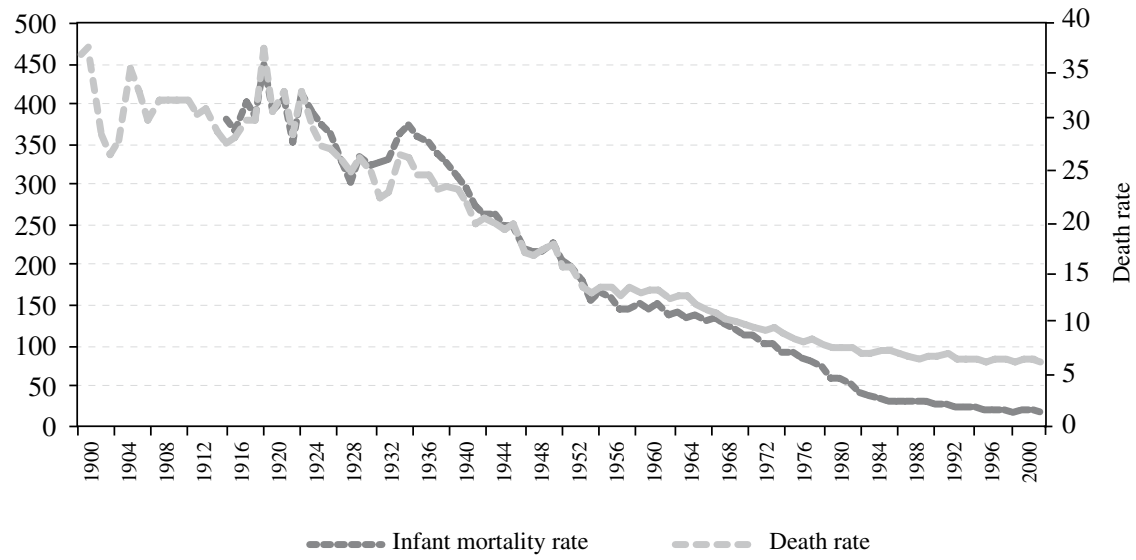

Source: Author's elaboration based on Díaz, Lüders and Wagner (2010).

Kaempffer and Medina (2006) study the evolution of the infant mortality rates in Chile in the period 1900-2003. They found a marked decrease in the infant mortality rates, especially between 1940 and 1950, which was attributed to the introduction of antibiotics that reduced the risk of various infectious diseases. In his analysis of the mortality in Valparaíso during the first half of the $20^{\text {th }}$ century, Cavieres (1999) emphasizes the role played by the government and other social actors (such as charity organizations ${ }^{1}$ ) in the reduction of mortality rates. According to him, the role of the government in reducing mortality was not limited to the creation of public health institutions; reduction in illiteracy also contributed in reducing deaths, especially those generated by infectious diseases. Allende (1939) and Raczynski and Oyarzo (1981) highlight the role of socioeconomic factors in explaining the evolution of the infant mortality rates and the demographic trends in Chile. Factors such as work conditions and poor nourishment led to poor health indicators, especially among the more deprived families. Figure 2 also shows periods of stagnation in mortality rates during 19501960 and at the beginning of the 1980 decade, explained by organizational problems in the National Health Service and by budget reduction in public health during the

1 Allende (1939) and Cavieres (1999) enlighten the long transition between the creation of charity institutions, as Beneficencia Pública or Gotas de Leche, and the consolidation of the government as the main promoter of the public health in Chile. References of the efforts made by the government in these issues can be found in Illanes (1993) and official documents of the time (Ministerio de Hijiene, Asistencia, Previsión Social i Trabajo, 1925). 
financial crisis of the 1980s (Raczynski and Oyarzo, 1981; Aguila and Muñoz, 1997; Kaempffer and Medina, 2006).

As consequence of the results described above, the population growth had a small downturn in the late 40 s, primarily explained by a period of low birth rate between 1930 and 1950. It then followed its increasing trend, reaching a peak of almost $2.5 \%$ in 1962. The large increase in the population rate between 1950 and 1962 is explained by a "baby boom" episode that occurred between 1955 and 1965, where the birth rate jumped from $32 / 1,000$ to $38 / 1,000$.

The data follows the patterns described by Lee (2003) as the first phase of the demographic transition: initial decline of mortality, mainly due to reduction in mortality at young ages, leading to an increase in the population growth rate. This phase lasted 50 years in the case of Chile.

Third Stage (1962-2000): The third stage is described by a process of continuous and quick decline in population growth between 1962 and 2000 (only reversed during the 1980s' decade). This situation is explained by the combined effect of a decline in both birth and death rates.

The decrease in mortality during this period follows the process initiated in the 1920 s, driven by the fall in infant mortality. The cause of this drop is largely found in the reduction of deaths by infectious diseases, and other problems associated with child mortality such as diarrhea and undernourishment. Medina and Kaempffer (2007) explore the trends of the Chilean mortality in the period between 1970 and 2000 , concluding that the decline in mortality can be explicated by the improvement of the general socioeconomic conditions, the modification of the health system and the advances in medical sciences. Other factors, such as the women educational levels have been also pointed out as possible explanations for this trend (Szot-Mesa, 2003).

Notwithstanding the impressive reduction in mortality, the more striking feature of this period is the decline in the birth rate. It began to fall constantly from 1963, with substantial but irregular falls between 1960 and 1970, and constant decreases since 1990. It is possible to observe a stagnation of the birth rate in the decade of 1980, a situation that explains the reverse in the population growth previously described. The decline of births in the 1960s coincides with the introduction of contraceptive methods in $\mathrm{Chile}^{2}$, although other variables, such as the decline in abortions and the reduction in infant mortality are used as alternative explanations (Donoso, Carvajal and Domínguez, 2009). The reduction of infant mortality is usually indicated as cause of reduction in fertility, since parents are ultimately interested in the number of children, not in the total number births (Freedman, 1961; Easterlin, 1975; BenPorath, 1976; Cerda, 2008; Donoso, Carvajal and Domínguez, 2009)³. Finally, the

2 Despite this effect, the program started in 1967 was not designed to reduce the birth rate. Its main goals were: i) lowering the rate of maternal mortality; ii) lowering infant mortality rates; iii) promoting family welfare by providing information for responsible procreation (Servicio Nacional de Salud, 1967).

3 The same argument is used to explain the effect in the opposite direction: excessive infant mortality is due in part to high birth rates and thus, family planning can reduce children mortality (Murillo, 1896; Bongaarts, 1987; Stoz-Mesa, 2003). 
government, through the implementation of the Programas de Planificación Familiar (Family Planning Programs) played an important role in the declining of the birth rate, even though their original goals were to decrease the death by abortion and fight the problem of undernourishment among pregnant women (Aguila and Muñoz, 1997).

\section{DEMOGRAPHY, ECONOMICS AND FISCAL POLICY}

The data on demographic variables presented in the previous section show important changes experienced by the Chilean society during the $19^{\text {th }}$ and $20^{\text {th }}$ centuries. Important changes are also observed when looking at the evolution of some macroeconomic variables.

First, the Chilean GDP has experienced important increases throughout the period of study, with an average growth rate of $3.3 \%$. The series exhibits a positive trend with marked increases from the mid-1930s and mid-1980s. Figure 3 also shows three marked periods of recession: from 1929 to 1932 (Great Depression), from 1971 to 1975 (Allende's government and coup d'etat), and between 1982 and 1983 (debt crisis). A similar trend is observed for GDP per capita, highlighting its faster growth since the last 20 years of study.

FIGURE 3

GDP AND GDP PER CAPITA, 1890-2000 (MILLIONS OF 1996 CLP)

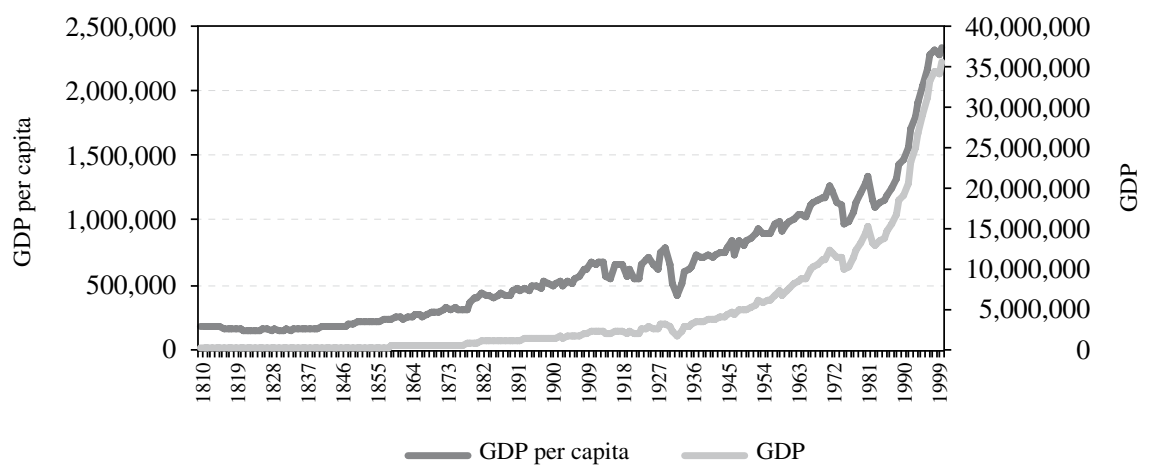

Source: Author's elaboration based on Díaz, Lüders and Wagner (2010).

On the other hand, fiscal decisions have changed accordingly. The extent of expenditure has grown pari passu with fiscal income, but showing an average fiscal deficit of $12.4 \%$ for the period 1833-2000. The period between 1864 and 1891 exhibits 
significant deficits (average -51\%) mainly explained by the wars against Spain (1865) and Peru and Bolivia (1879 and 1882).

Figure 4 also shows differences in the ratio fiscal expenditure to GDP. The data shows a constant increase in this relation, reaching a maximum of 35\% in 1972. The ratio fiscal expenditure to GDP decreases during the 1990s, standing around 20\% until 2000.

\section{FIGURE 4}

FISCAL INCOME, FISCAL EXPENDITURE AND FISCAL EXPENDITURE/GDP, 1833-2000 (MILLIONS OF 1996 CLP)

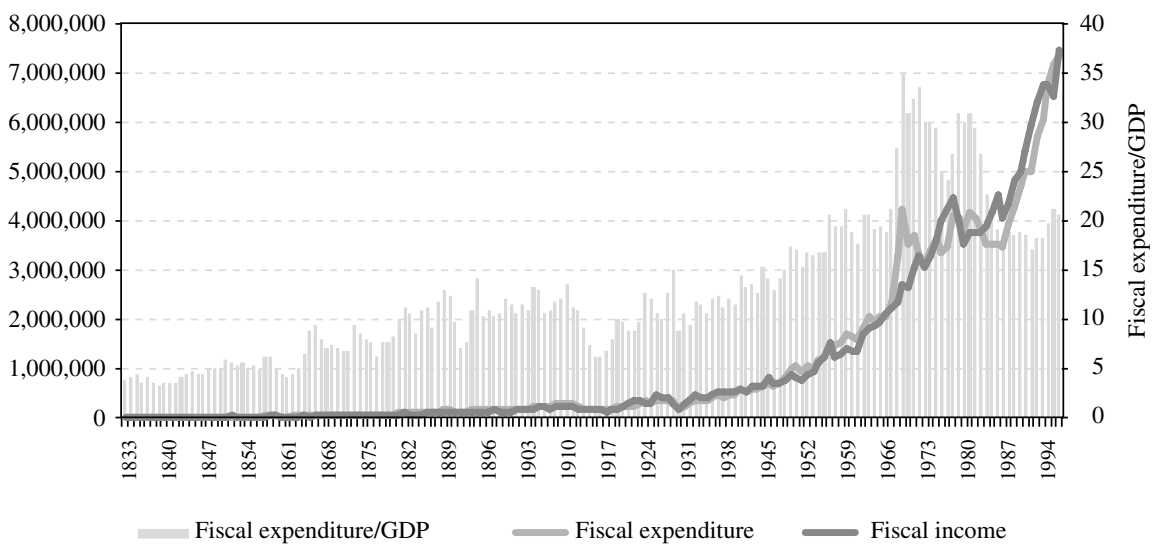

Source: Author's elaboration based on Díaz, Lüders and Wagner (2010).

Are these two phenomena -demographic transition and fiscal changes- related? If so, how can we understand the relation between both? Since the work of Malthus (1798), the link between demographic and economic variables has been extensively studied. Kuznets (1966) stressed the parallel between increase in life expectancy and improvement of economic conditions, measured by economic growth and personal consumption. However, the relationship between both types of variables is far from being completely understood: the reverse causality imposes major challenges for the analysis ${ }^{4}$. As Bairoch (1993) points out "the empirical and comparative study of the interrelation between population and economic growth remain one of the least explained areas in the field of demographic economic interrelation". The literature

4 See Schultz (2010) for a description of the relationship between health (related to demographic characteristics as fertility and mortality) and development. For a review of the literature on the interaction between demographic and economic variables, see Coale and Hoover (1958), Birdsall (1988) and Schultz (2010). 
has addressed these challenges dividing them into two broad branches: economic determinants of demographic transition and impact of demographic variables on economic output. In the case of Chile, the literature on demography and economics is recent and scarce. Castillo (2005), Larrañaga (2006) and Cerda (2006, 2008) are some of the few efforts made to understand the link between economic and demographic variables in the country.

The literature on demand for public (or publicly provided) goods and government expenditure has been mainly focused on the estimation of income and price elasticities, resulting in little consensus about the role of demographic characteristics in determining public expenditure (MaCurdy and Nechyba, 2001). Recently, the relevance of population ageing and other demographic features have emerged through the study of the determinants of government spending (Lindert, 1996; Painter and Bae, 2001; Sanz and Velásquez, 2007; Potrafke, 2008).

Demographic transition creates a series of major changes in the structure of the population. These changes lead to significant modifications in the needs (demand) and capabilities (supply) of the economy, generating new challenges for the government and, consequently, imposing changes in public policies (Coale and Hoover, 1958; Lee, 2003; Cigno and Werding, 2007; Ito and Rose, 2010). In particular, demographic characteristics alter not only the scale of the population, but its age distribution ${ }^{5}$. These changes are the main channel -although not the only one- through which demography affects the economy (Lee, Arthur and Rodgers, 1988; Lee, 2003). But, how are these changes in demography transformed into a fiscal policy response?

Consider an economy consisting in consumers, firms and government. Consumers can be defined by a series of characteristics, but in this case, population is fully described by its age distribution. Particularly, in each period consumers can be divided into young, adult and elderly population. Each type of population has general and specific needs, which leads to the existence of markets for general and specific goods. While specific goods are consumed intensively (or exclusively) by a determined population, the demand for general goods is equal across populations. If the government acts as complement of the private sector in the provision of "key goods" 6 then, increases in population raises the demand for those goods, pressing the government to cover the difference between demand and private supply on each market.

Under these assumptions, the effect of the change in the age profiles in a given economy can be summarized as follows ${ }^{7}$ :

5 In the case of large migratory movements it is also possible to add changes in the skill distribution.

6 Goods considered as basic or minimum needs. Princhett and Woolcock (2008) define "key services" as "... those for which there is a broad consensus that some type of government action is necessary, desirable or inevitable". They include in this classification the provision of clean water, education, sanitization, safety, and public health, among others. Sanz and Velásquez (2002) use the term "merit goods" in reference to health, education and housing, while considering social welfare spending as transfers. For Feldstein (1975), "categorical equity goods" are those "... which are deemed to be "fundamental interests" and asserts that individuals' consumption of these services should not be allowed to differ substantially or, alternatively, that such difference should not bear a strong relation to the individuals' "ability to pay"'. He includes education and health care in this group.

7 See Appendix 1 for a derivation of the results. 
Result 1: Total population has uncertain impact on the government expenditure, both in general and specific goods: increases in population raise the demand for general and specific goods, but also increases the private labor supply.

Result 2: Adult population affects negatively the public expenditure in specific goods consumed by the other groups (young and elderly), while has an uncertain effect on expenditure in adult-specific and general goods: adult population determines the private labor supply and the demand for adult-specific goods, but does not impact on the demand of young and elderly-specific goods.

Result 3: Fiscal expenditure in specific goods (for young and elderly populations) depends positively on the population consuming intensively those goods: more young (elderly) people increase the fiscal expenditure on young (elderly) specific goods.

Result 4: Fiscal expenditure in general goods reacts positively to the young and elderly population, for a given adult population.

As shown in Figure 5, the Chilean data shows important differences not only in the level of expenditure, but also in its composition.

\section{FIGURE 5}

SOCIAL EXPENDITURE AND DISTRIBUTION, 1850-2000 (MILLIONS OF 1996 CLP)

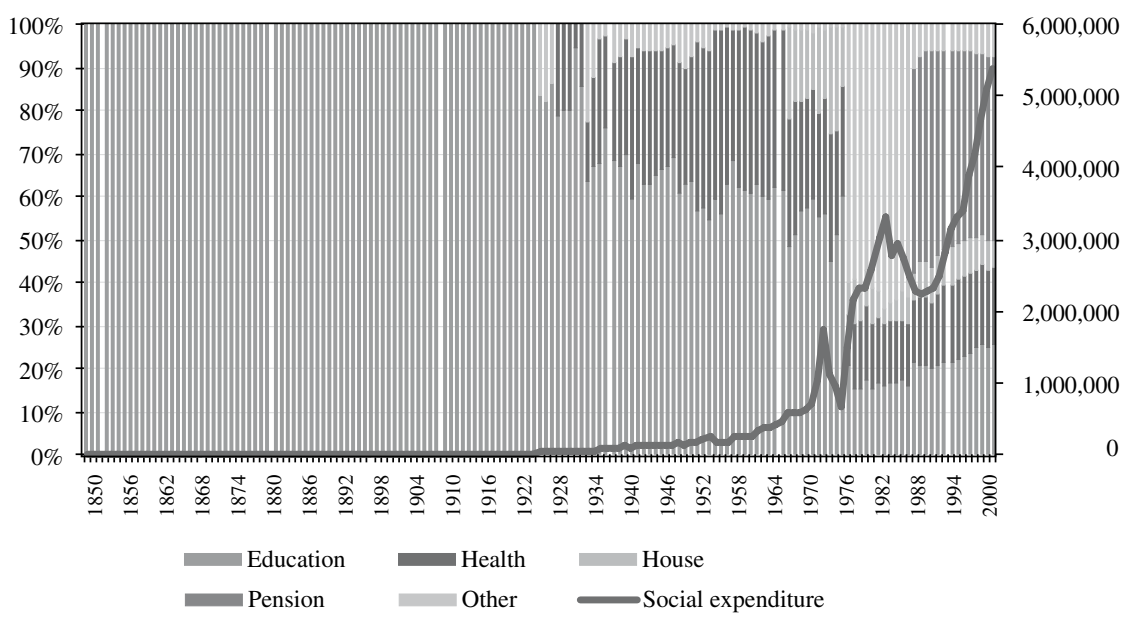

Source: Author's elaboration based on Díaz, Lüders and Wagner (2010). 
The social expenditure exhibits a trend similar to that followed by the fiscal expenditure. It is also noted that the distribution resources have changed drastically over the period, with a preponderance of educational expenditure in the initial years, and important reallocations in the last years.

The analysis of the social (public) expenditure is important because of its increasing importance in the fiscal expenditure, and because its components can be classified as expenditure in general and specific goods.

\section{EMPIRICAL METHODOLOGY}

The previous results were tested using historical annual data from Chile (Díaz, Lüders and Wagner, 2010). The estimation takes the form:

$$
\text { Public Policy }=\beta_{1}+\beta_{2} \text { Demography }+\beta_{3} X+\varepsilon
$$

where Public Policy is measured by fiscal expenditure, Demography is a matrix of demographic characteristics, $X$ is a matrix of other control variables, and $\varepsilon$ is the error term. Following the explanation in Section 3, different equations are needed to capture the effects summarized above. In order to capture the impact on the governmental supply of general goods, equation 4.1 is estimated by:

$$
G E^{G}=\beta_{1}+\beta_{2} \text { Demography }+\beta_{3} X^{G}+\varepsilon
$$

where $G E^{G}$ is the government expenditure on general goods, and $X^{G}$ is a matrix of other variables affecting the government expenditure on general goods. Similarly, different equations are estimated to capture the effects on the supply of specific goods:

$$
\begin{aligned}
& G E^{S, Y}=\beta_{1}+\beta_{2} \text { Demography }+\beta_{3} X^{S, Y}+\varepsilon \\
& G E^{S, A}=\beta_{1}+\beta_{2} \text { Demography }+\beta_{3} X^{S, A}+\varepsilon \\
& G E^{S, E}=\beta_{1}+\beta_{2} \text { Demography }+\beta_{3} X^{S, E}+\varepsilon
\end{aligned}
$$

where $G E^{S, Y}, G E^{S, A}$, and $G E^{S, E}$ are the public expenditure on specific goods for the young, the adults and the elder, respectively. As before, the matrices $X$ represent other variables affecting the government expenditure.

As a first step, equations 4.2 to 4.5 are estimated using the share of expenditure on different items (as percentage of the social public expenditure) and the share of population in every age group (young, adult and elderly). In defining general and specific goods, previous classifications were used (MaCurdy and Nechyba, 2001; Cigno and Werding, 2007). Education is considered as a young-specific good, while social security is an elderly-specific good. Health and housing are defined as 
general goods ${ }^{8}$. Unfortunately, the database has only 18 observations in which the population's age composition is available. An alternative strategy is used to check the results of the first part and to allow for some extensions.

In the second part, population changes are used to infer the distribution (or changes in distribution) of ages in each period. Using data from 1910 to 2000, it is possible to break down the sample of years into different periods, similar to those stated in Section 2. The first period (1910-1962) is characterized by the beginning of the mortality rates decline, combined with a high birth rate. If most of the decline in death rate comes from the decrease in children's mortality rates, instead of changes in the death rates of other groups (adults and elders), then the growth of population experienced during 1910 and 1960 can be thought as non-neutral, and particularly, biased towards young population. Figure 2 shows some evidence supporting this view.

However, it is necessary to demonstrate that death rates of the other groups do not change (or change less than the rate experienced by the young) for using this approach. Figure 6 shows that during the first years of the period, life expectancy at birth was relatively low and constant (around 30 years) ${ }^{9}$. This pattern changed around mid-1920, when life expectancy began to increase sharply, going from 31 years in 1922 to 40 in 1937, and to 54 years in 1950. From that point on, life expectancy began to rise constantly, reaching a growth of $1 \%$ in the 1970 s. The year 1979 marks a breakpoint in the tendency, and from that year until today, the life expectancy has continued growing at decreasing rates, going from 70 years in 1980 to 77 years in 2000 .

The data on life expectancy sheds light on the changes in mortality rates between young and old people. Even though it is a very rough measure of changes in elderly mortality rates -in fact, it changes as a response to changes in child mortality rate too- it can be used to infer the age patterns in the population. It is possible to argue that life expectancy at birth did not change too much until mid-1920s ${ }^{10}$. If the average age of death was around 30 years, then cohorts born before 1925 , lived on average until 1955. But when did the elderly became older? Although the answer is not clear from this analysis, it was certainly not before 1955 . This finding suggests that during the first stage (between 1910 and 1962) the population grew, and this growth is explained by the growth of young people. In terms of the analysis, during this period the young dependency ratio ${ }^{11}$ should have increased. Likewise,

8 Although health can be viewed as consumed more abundantly by particular groups, it is hard to decompose it in the same way that education. Health is more heavily consumed by young and older people, and by adult women.

9 Life expectancy at birth is defined as the average number of years a newborn child would live if current mortality patterns were to stay the same.

10 The oldest available data shows that in 1902 the life expectancy at birth was 32 years, while 20 years later it was 31.6.

11 The (child) youth dependency ratio is defined as $\left(\frac{\text { Young population }}{\text { Adult population }}\right)$. Similarly, it possible to define the elderly (old-age) dependency ratio $\left(\frac{\text { Elderly population }}{\text { Adult population }}\right)$ and the total dependency ratio $\left(\frac{\text { Young }+ \text { Elderly population }}{\text { Adult population }}\right)$. 
the 1960-2000 period reflects a clear pattern in terms of population growth. During those years, population decrease is explained by the decay in the birth rate. The previous high rate of birth combined with the new lower rates of birth resulted in an increase of the adult population and a decrease of the young population, reducing the youth dependency rates. The generation born after 1960 also enjoys a higher life expectancy (around 60 years). If we think of people leaving the labor force at the age of $60^{12}$, then many of the people born between 1910 and 1962 worked most of their life, with few or no years as pensioners. By 1965, population's life expectancy reached 60 years, and began putting pressure on the pension system. Generations born after 1965 entered into the labor force around 1980 (15 years), and they are expected to retire from the labor force around 2030. This implies that Chile is actually in a transition between the second and the third phase of the demographic transition. During the period of 1962-2000, it is expected to observe a reduction in the youth dependency ratio, as well as a decrease in the total dependency ratio. The explanation for this pattern is the increase of the labor force after the peak of population growth in the 1960s, the reduction of birth rates, and the still not present effects of the elderly population in the Chilean economy.

\section{FIGURE 6}

LIFE EXPECTANCY AT BIRTH, 1902-2000

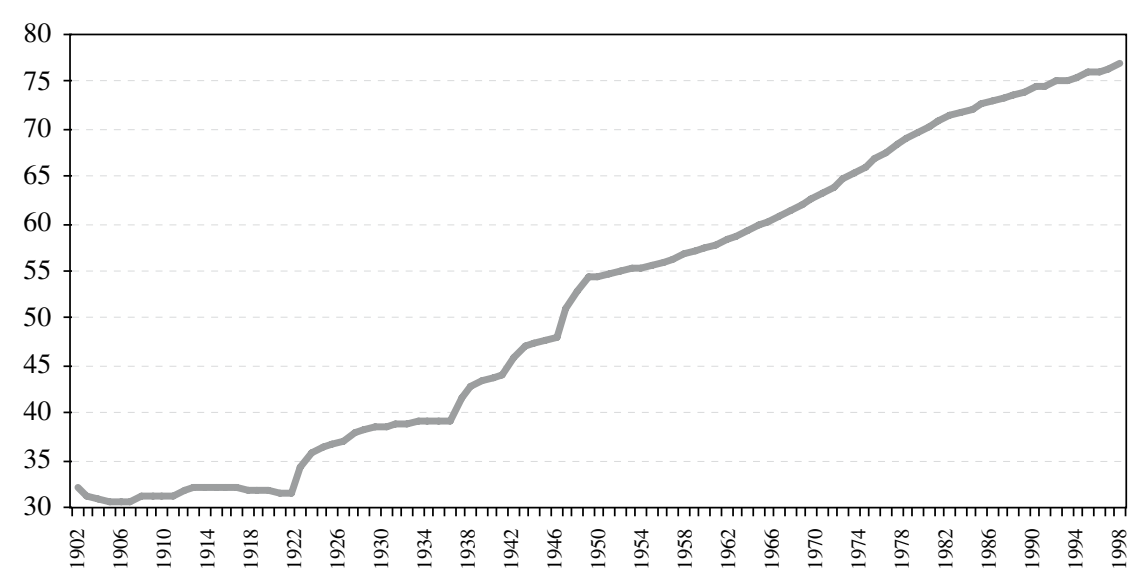

Source: www.gapminder.org.

12 Minimum retirement age before the 1981 pension reform was 60 for men and 55 for women. 
An additional caveat is needed before continuing. Until now the analysis has been focused on the effects of population growth explained by birth and mortality rates, but an important variable has been excluded: migration. In many cases the effects of migration in countries can be significant, changing the results ${ }^{13}$. Even if migration data were available, it would be necessary to make additional assumptions to evaluate the effect of this variable in the results. The data from Diaz, Lüders and Wagner (2010) contains information about the number of foreign residents in Chile since 1854, allowing the assessment of its effects.

As shown in Table 1, the number of foreign residents in the country corresponds just to a small fraction of the total population, and it has been decreasing continuously since 1885 . If births and deaths of foreign residents are already captured by birth and death rates, then migration is roughly equal to the number of residents. With these numbers in mind, it is possible to argue that the migration is negligible in Chile for the period of study.

\section{TABLE 1}

FOREIGN RESIDENTS IN CHILE

\begin{tabular}{|cccccccccccccc|}
\hline Year & 1854 & 1865 & 1875 & 1885 & 1895 & 1907 & 1920 & 1930 & 1952 & 1960 & 1970 & 1982 & 1992 \\
\hline $\begin{array}{c}\text { \% of } \\
\text { population }\end{array}$ & 1.30 & 1.22 & 1.20 & 3.58 & 2.84 & 4.19 & 3.24 & 2.47 & 1.64 & 1.38 & 0.95 & 0.70 & 0.80 \\
\hline
\end{tabular}

Source: Díaz, Lüders and Wagner (2010).

\section{DATA AND RESULTS}

The main source of information is the dataset constructed by Díaz, Lüders and Wagner (2010), covering 200 years of history for Chile. The dataset contains information on different topics, such as production, national accounts, prices, international exchange, monetary and finance statistics, and human resources.

The left hand variables in equations 4.2 to 4.5 , capturing the "Public Policy", are defined as components of the social expenditure: education, health, housing, and pensions. This classification permits view the changes in each variable as changes in the government's priorities, for a given social budget.

As mentioned before, the variable "Demography" is described in two complementary ways. First, it is used the share of population in every age group (young, adult and elderly), i.e., a direct description of the distribution of ages in the population. Because the scarcity of data, a second definition is employed, using birth and death rates, in order to identify the demographic structure of the population at different periods of time.

13 Migration has been neglected as an important factor explaining population changes. It is usually assumed that they are mainly driven by mortality and fertility levels (Freedman, 1961). 
Finally, the matrix $X$ attempts to control for other factors, different from demographic characteristics of the population that can influence the government expenditure ${ }^{14}$. Following the empirical literature ${ }^{15}$ (Painter and Bae, 2001; Merrifield, 1996) we can classify the factors affecting public expenditures in three groups ${ }^{16}$ : demographic, political and institutional determinants. Demographic determinants have been already noticed as a main factor determining government's decisions, and include population dynamics and composition. This component has been addressed in several studies as crucial in determining the public expenditure (Painter and Bae, 2001; Lindert, 1996; Sanz and Velásquez, 2007; Potrafke, 2008). Political elements, such as the effect of an election year or the coalition in power (left-right axis) are also stressed as plausible explanations for the levels and distribution of public expenditures (Downs, 1957; Shi and Svensson, 2006; Potrafke, 2008). Lastly, institutional determinants are associated to particular features of the institutional system, such as the existence of a federal government, constitutional constraints for the decision-making process or the degree of privatization in the economy (Oates, 1972; Kappeler, 2008).

As political factor it is included a dummy for right-wing governments, trying to capture differences in preferences for expenditure categories among different political ideologies. This classification is far from being evident, especially for older periods, in which political parties and political environment differ greatly from the actual. Rightwing governments are defined according to the president's party, and include members from the Conservative Party, Liberal Party, National Party, as well as independent presidents (Jorge Alessandri and Augusto Pinochet). Besides, it is included a dummy for election years, intended to capture changes in the government's behavior before an election (Shi and Svensson, 2006; Potrafke, 2008).

The institutional factors have been assessed in several studies (Kappeler, 2008; Ohtake and Sano, 2010; MaCurdy and Nechyba, 2001; Echevarría, 1995), exploiting the existence of fiscal federalism regimes, that affects not only the level, but the composition of public spending. In the case of Chile, the analysis is carried out at national level, and the budgetary process is assumed to be a centralized one, making impossible to include this kind of analysis. However, there are other relevant features of the Chilean history that can be useful to analyze. Every year, the budgetary allocation must be approved by the Congress, making this requirement the main control mechanism for government expenditure ${ }^{17}$. This mechanism was particularly relevant for the pre1925 period, the Parliamentary Regime, which ended with the Constitution of 1925. In order to capture this characteristic, a dummy variable is included to account for

14 A summary of studies on the determinants of public expenditure can be found in Tridimas (2001) and Sanz and Velásquez (2002).

15 For a theoretical discussion, see Persson and Tabellini (2000).

16 These groups are useful to identify different dimensions affecting the government's budgetary decisions, but are arbitrary. For example, Wagner's law describes different channels determining the public expenditure (Musgrave, 1959; Hindriks and Myles, 2006). Lindert (1996) classifies the variables in income effects, electoral variables and age distribution. A summary of theories can be found in Mourao (2007).

17 From 2001 the Chilean fiscal policy is based on the concept of "structural balance", which determines the maximum level of government expenditure. This feature was not active during the period of study. 
the years in which the Congress ceased its functions ${ }^{18}$. The rationale for this is that during those years the Congress' control over public budget was null, allowing the president to spend more freely ${ }^{19}$.

Finally, the ratio fiscal income/GDP is incorporated as a way to measure the budgetary constraint of the government. This variable can also be interpreted as a relevant feature of the government and the political institutions of the country: the state's ability to raise taxes is a sign of its autonomy and capacity (Schumpeter, 1918; Kaldor, 1963; Tanzi, 1981).

The descriptive statistics of the variables used in this study are showed in Table 2. The definition of each variable is presented in the Appendix $2^{20}$.

\section{TABLE 2}

\section{DESCRIPTIVE STATISTICS}

\begin{tabular}{|lrrrrr|}
\hline Variable & Obs & Mean & Std. Dev. & Min & Max \\
\hline Total expenditure (ln) & 168 & 12.404 & 2.041 & 8.676 & 15.905 \\
Social expenditure (ln) & 159 & 10.582 & 2.778 & 5.141 & 15.494 \\
Education expenditure (ln) & 159 & 10.172 & 2.330 & 4.360 & 14.143 \\
Health expenditure (ln) & 73 & 11.680 & 1.369 & 7.702 & 13.780 \\
House expenditure (ln) & 35 & 12.131 & 0.404 & 11.445 & 12.713 \\
Pension expenditure (ln) & 14 & 14.199 & 0.262 & 13.859 & 14.641 \\
Education/social expenditure & 159 & 0.752 & 0.295 & 0.150 & 1 \\
Health/social expenditure & 159 & 0.112 & 0.135 & 0 & 0.426 \\
House/social expenditure & 159 & 0.022 & 0.049 & 0 & 0.243 \\
Pension/social expenditure & 159 & 0.039 & 0.1290 & 0 & 0.501 \\
Population share of young (\%) & 18 & 46.168 & 4.50 & 36.39 & 51.25 \\
Population share of adult (\%) & 18 & 50.969 & 3.791 & 47.071 & 58.97 \\
Population share of elderly (\%) & 18 & 2.862 & 0.846 & 1.51 & 4.64 \\
Birth rate & 151 & 34.159 & 7.124 & 12.223 & 45.861 \\
Birth rate (25 lag) & 126 & 36.698 & 4.579 & 24.233 & 45.861 \\
Death rate & 151 & 20.719 & 9.772 & 5.181 & 37.397 \\
Ratio fiscal income/GDP & 159 & 12.420 & 7.359 & 3.66 & 33.17 \\
Right-wing government & 159 & 0.647 & 0.479 & 0 & 1 \\
Election year & 159 & 0.182 & 0.387 & 0 & 1 \\
Congress closed & 159 & 0.132 & 0.339 & 0 & 1 \\
Parliamentary regime & 159 & 0.522 & 0.501 & 0 & 1 \\
\hline
\end{tabular}

18 The information on these dates was obtained from http://www.camara.cl/camara/historia_congreso. aspx. Two of these episodes are related to the budgetary discussion itself. The closure of the Congress in 1891, situation that started a civil war, was due to the rejection of Balmaceda's government budget by the Congress (San Francisco, 2007). On the other hand, in 1924 the Congress was dissolved by president Alessandri, after the formation of a Military Committee. The genesis of this situation was the interruption of a group of low-range military during the budgetary discussion in 1924. The incident is known as Ruido de sables (Gazmuri, 2011).

19 Quoting Illanes (1993) "Once the Parliament was closed and the state of siege was declared, the Military Board was set in power... It was September 11, 1924. The national budget, trapped in the Congress, was approved immediately..." (Illanes, 1993, pp. 202).

20 As shown in the Appendix, the expenditure variables are defined in a broad sense, in order to capture the whole cost bore by the government. This includes not only the cost of policies and programs, but also administrative costs. 


\section{Results using population shares}

The first set of estimations uses data on population shares from 1885 to 2000 to measure the impact of demographic transition in fiscal expenditures. Figure 7 shows the pronounced changes in the population's composition by age. While young population (between 0 and 19 years) has dropped drastically, adult and elderly populations exhibit a marked increase since mid-1960s. Finally, during the last years the elderly population growth became steeper.

\section{FIGURE 7}

POPULATION SHARES, 1885-2000

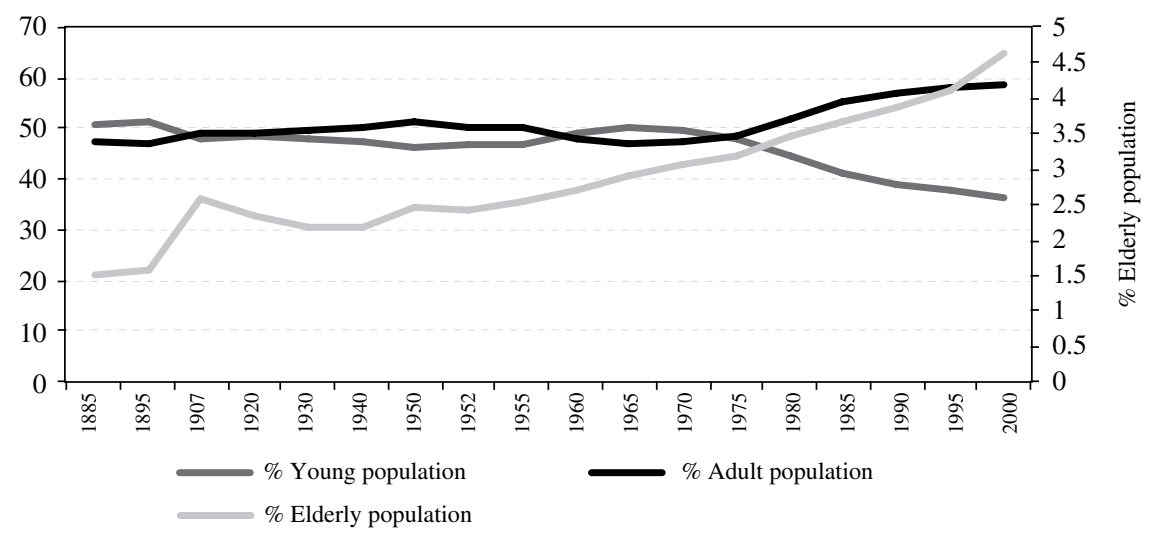

Source: Author's elaboration based on Díaz, Lüders and Wagner (2010).

The results from Section 3 can be tested with a graphical analysis. Figure 8 shows the relationship between the share of expenditure in different goods (education, health, housing, and pension) and the share of populations (young, adult, and elderly).

First, it is observed a marked positive relationship between government expenditures and the young and elderly population in the case of specific goods (education and pension), while this relationship is less clear for general goods (health and housing), which can be interpreted as $\frac{\partial_{g_{G}}}{\partial_{N}}<\frac{\partial_{g_{S}}}{\partial_{N}} 21$. Second, the adult population shows a negative relationship respect to the expenditure on education (expected), but positive with respect to pensions (unexpected). Third, the expenditure on specific goods exhibits

21 Alternatively, the difference can be due to differences in the cost of provision of the goods, $c^{\text {General }}$ and $c^{\text {Specific }}$ (see Appendix 1). 


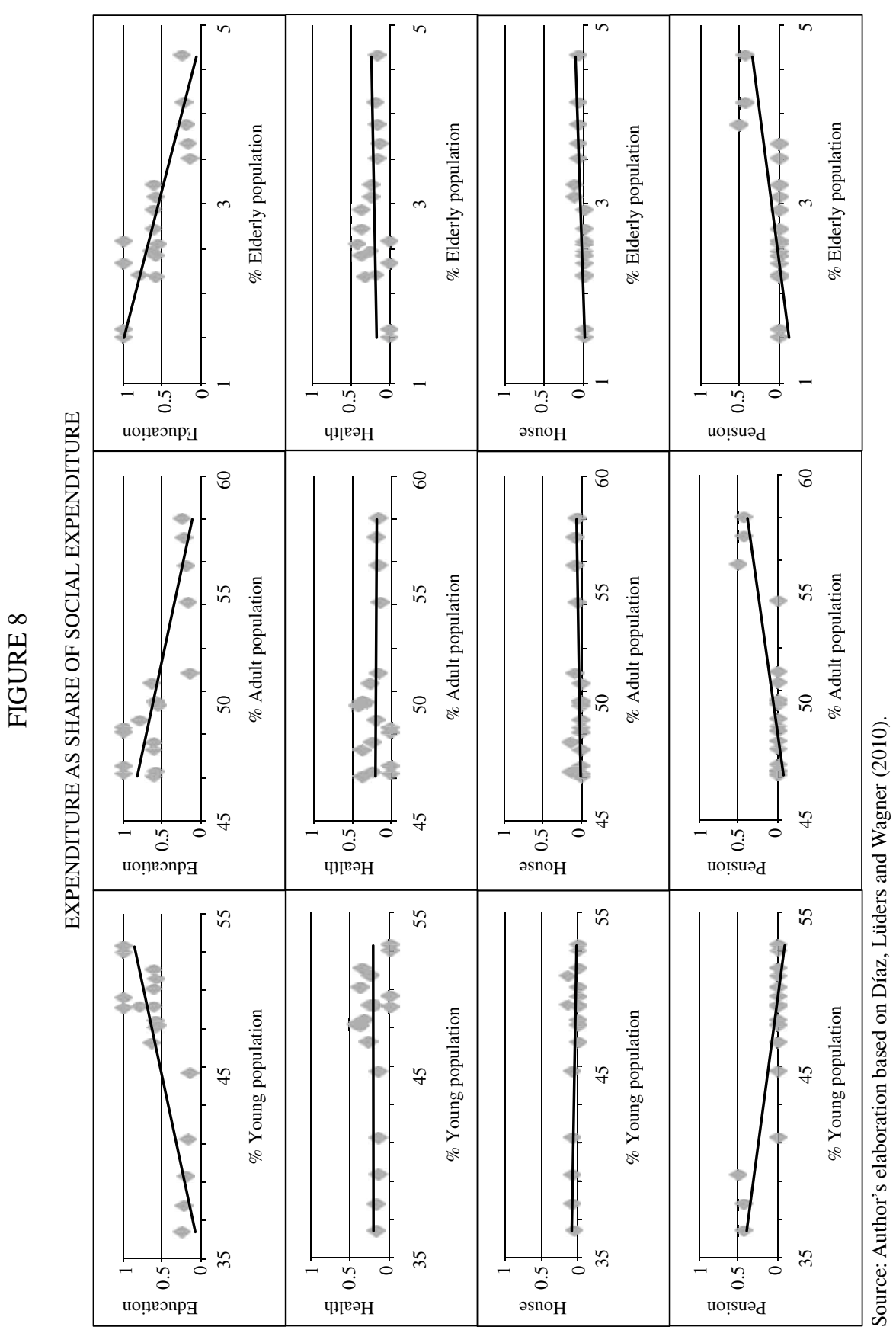


a positive and higher correlation with the population that consumes intensively that good (young-education and elderly-pension). Fourth, as expected, the expenditure on general goods exhibits a positive correlation respect to elderly and young population (except for housing expenditure and young population).

The previous results are assessed estimating Equations 4.2 to 4.5, using population share by ages as Demography variable, and adding political and institutional variables. It worth noting that equation 4.4 (impact of changes in the adult population on the government expenditure in specific adult goods) cannot be estimated using this dataset. Although it is possible to think of specific adult goods (i.e. employment), it is hard to disentangle the expenditure in a way that allows to identify the specific spending in employment. The results for the different expenditures are shown in Table 3.

Columns (1) and (3) show the lower effect of adult population on expenditure for each of the goods, compared to the impact of young and elderly population, except for expenditure on pensions. The share of young population has a positive effect on the educational expenditure, a positive but not statistically significant effect on the expenditures of general goods (health and housing), and negative impact on the expenditure of pensions. Finally, the percentage of elderly population shows no impact on the expenditure of any good.

\section{TABLE 3}

EXPENDITURE SHARE REGRESSIONS, 1885-2000

\begin{tabular}{|lcccc|}
\hline Variables & $(1)$ & $(2)$ & $(3)$ & $(4)$ \\
& Education & Health & House & Pension \\
\hline \% Young population & $0.0309^{* * *}$ & 0.0102 & 0.000829 & $-0.0348^{* * *}$ \\
& $(0.00846)$ & $(0.00903)$ & $(0.00887)$ & $(0.0103)$ \\
\% Elderly population & 0.157 & -0.112 & 0.000798 & -0.00946 \\
& $(0.106)$ & $(0.108)$ & $(0.0604)$ & $(0.117)$ \\
Fiscal income/GDP & -0.000483 & $-0.00930^{* *}$ & $0.00718^{* * *}$ & 0.00316 \\
& $(0.00602)$ & $(0.00298)$ & $(0.00146)$ & $(0.00615)$ \\
Right-wing government & -0.0181 & 0.0617 & -0.0174 & -0.0230 \\
& $(0.0429)$ & $(0.0345)$ & $(0.0249)$ & $(0.0475)$ \\
Congress closed & $-0.222^{* *}$ & $-0.0916^{* *}$ & -0.0318 & $-0.231^{* *}$ \\
& $(0.0921)$ & $(0.0294)$ & $(0.0194)$ & $(0.0902)$ \\
Parliamentary regime & 0.0484 & $-0.244^{*}$ & $0.0698^{* *}$ & 0.141 \\
& $(0.177)$ & $(0.111)$ & $(0.0261)$ & $(0.126)$ \\
Trend & $-0.00727^{*}$ & 0.00493 & 0.000513 & 0.00121 \\
& $(0.00401)$ & $(0.00329)$ & $(0.000725)$ & $(0.00314)$ \\
Constant & -0.501 & -0.252 & -0.189 & $1.533^{* *}$ \\
& $(0.496)$ & $(0.506)$ & $(0.498)$ & $(0.531)$ \\
\hline Observations & 18 & 18 & 18 & 18 \\
\hline Adj. R-squared & 0.939 & 0.836 & 0.585 & 0.810 \\
\hline
\end{tabular}

Robust standard errors in parentheses.

$* * * \mathrm{p}<0.01, * * \mathrm{p}<0.05, * \mathrm{p}<0.1$. 
These results partially support the predictions stated in Section 3. The negative effect of the adult population appears in each regression (Result 2), except for pensions. Result 3 states a positive effect of the population that consumes intensively the specific good; this result holds in the case of education. The positive effect on general goods (health and housing) postulated by Result 4 holds for the young population, while the elderly population exhibits not significant or negative impact. In any case, the impact of population on general goods is smaller than the effect registered on specific goods.

The control variables (institutional and political factors) exhibit dissimilar results. The ratio fiscal income over GDP correlates negatively with health expenditure and positively with housing expenditures. The dummy variable for periods when the Congress ceased its function shows a negative and significant effect for almost any estimation, which is counterintuitive at first glance. The reason is because the sample, which covers a period between 1885 and 2000, includes only selected periods for which the data on population shares is available (usually every 5 years). The only observations in the sample for which the Congress was closed are 1980 and 1985, both reflecting considerable reductions in the relative importance of educational, health and housing expenditures. The positive effect of the period on pensions is not captured, since this expenditure started in 1988. The dummy for the parliamentary period also differs between estimations, while the variable capturing the political ideology of the president in power shows no significant effect. The use of dummy variables is in these estimations is limited, since many interesting years are omitted from the sample.

The results can be contrasted with those found by other authors. MaCurdy and Nechyba (2001) employ a cross section of Californian counties to measure the impact of demographic features on government expenditures. They use the expenditure share in education, health, welfare, police and fire, and infrastructure to assess the impact of the proportion of young and elderly population, controlling by median income and fraction of rural households. Their results suggest a positive effect of the young population on education shares and no significant effects on health shares, similar to those obtained from Table 3. Ohtake and Sano (2010) inquiry into the determinants of the Japanese public expenditure on education, using panel data at prefectural level between 1975 and 2005. They find a negative effect of young population and mixed effects for the elderly population. The changing effect of the elderly population between periods is interpreted as being produced by the change in the subsidy for compulsory education during the mid-1980s. Even though their analysis is focused on the effect of the elderly on education expenditure, the negative impact of the young population in educational expenditures is somehow surprising. The reason for this result is the use of per-pupil educational cost as dependent variable: increases in population old enough to receive compulsory education decrease education costs per-student. Additionally they use variables in logs, and present graphical evidence supporting this relationship. The scatter plot between education expenditure and young (and elderly) population in logs for the Chilean data presents the same pattern (not shown), however the estimation does not confirm a negative relationship between educational expenditure and young population. Using the Mackinnon, White and Davidson test (1983) to determine the specification of the model, the use of a logarithmic over a lineal relationship is discarded for the education and health regressions. 
Results are robust when estimating the equations in logarithms and when taking into account autocorrelation in the residuals (Newey-West standard errors). Results also hold when using a different definition for the left-hand variables (level of expenditure) and adding covariates (level of social expenditure). However, the results are far from being conclusive, especially considering the lack of observations and the potential endogeneity problem. Additionally, most series present orders of integration higher than zero and no cointegration, implying that the coefficients show spurious correlations.

\section{Results using population changes}

The second series of estimations use population changes to test the results presented in Section 3. Notwithstanding the additional assumptions needed to interpret these results, the data permits to increase considerably the number of observations and inquire into some dynamic effects, enriching the understanding of the relationships between population change and government expenditure.

The first estimation shows the results of equations 4.2 to 4.5 for the period 1850-2000. According to the results presented before, it is expected an impact of the population change (general population change) on government expenditure, which can differ between general and specific goods. This result is explained by the opposite effects of adult and non-adult populations. As before, the order of integration of each series was inspected, finding that most of the series are I(1) but their lineal combination is $\mathrm{I}(0)$, showing the existence of a cointegration relationship between the variables. Other variables of interest, such as total population and number of workers in each period (labor force), were excluded from the analysis because they presented higher orders of integration, and do not allow cointegration of the series. This strategy rules out the possibility that results are due simply to spurious correlation, and permits to interpret them as a long-run equilibrium. In this case, the combination of birth and death rates gives an approximation to population change (see Figure 1), while the lagged population rate captures the changes in the labor force.

Column 1 in Table 4 shows the determinants of total expenditure. The left-hand variable is defined as the logarithm of total government expenditure. Result 1 indicates that the impact of total population on expenditure is uncertain and depends on the interaction between the cost of providing goods, the impact of population on the demand, and its impact over the private supply. Although the coefficient of the birth rate is not statistically significant, the death rate shows a negative impact, which can impact positively the total population, for example between 1920 and 1965. On the other hand, the lagged birth rate also shows a negative coefficient, showing that more population in working age diminishes total fiscal expenditures (Result 2).

When looking at expenditures on specific goods, the conclusion is reinforced: except for the results in column (5), all the estimations show a positive effect of birth rate on expenditure, as well as a negative effect of the lagged birth rate. A possible interpretation is that higher population (higher birth rate and lower death rate) impacts positively on the fiscal expenditure on specific goods (Result 1) controlling for changes in the adult population. Lagged birth rate also shows negative effects for expenditures in education and housing, in line with Result 2 . In the case of pensions, the positive 
coefficient can be interpreted as the pressure added to the social security system by the increase in future pensioners.

For educational expenditure, birth and death rates show positive effects. The result of birth rate is intuitive, since higher birth rates mean more children. The coefficient of death rates is somehow counterintuitive; however, the result could be explained arguing that, for a given young population, an increase in death rates of the other groups increase the relative importance of the young population, encouraging higher expenditures in education.

Birth rate shows a positive impact on health expenditure, while there is a negative effect of the death rate: more children correlate positively with health expenditure, and more deaths do it negatively. The result indicates that it is not population itself what determines health expenditure, but changes in specific populations i.e., those who require more health services (young and elderly population).

\section{TABLE 4}

IMPACT OF DEMOGRAPHY ON GOVERNMENT EXPENDITURES, 1850-2000

\begin{tabular}{|lccccc|}
\hline Variables & $(1)$ & $(2)$ & $(3)$ & $(4)$ & $(5)$ \\
& Total & Education & Health & House & Pension \\
\hline Birth rate & -0.006 & $0.019^{* * *}$ & $0.021^{*}$ & $0.095^{* *}$ & 0.007 \\
& {$[0.94]$} & {$[3.03]$} & {$[1.85]$} & {$[2.21]$} & {$[0.65]$} \\
Birth rate (lag 25) & $-0.018^{* *}$ & $-0.016^{* *}$ & 0.013 & $-0.089^{* * *}$ & $0.008^{* *}$ \\
& {$[2.34]$} & {$[2.17]$} & {$[0.69]$} & {$[3.61]$} & {$[2.99]$} \\
Death rate & $-0.020^{* *}$ & $0.016^{* *}$ & $-0.088^{* * *}$ & $-0.267^{*}$ & 0.03 \\
& {$[2.28]$} & {$[2.37]$} & {$[5.02]$} & {$[1.71]$} & {$[0.94]$} \\
Social expenditure (ln) & & $0.636^{* * *}$ & $1.023^{* * *}$ & $0.726^{* * *}$ & $0.949^{* * *}$ \\
& & {$[4.58]$} & {$[4.42]$} & {$[2.99]$} & {$[9.90]$} \\
Fiscal Income/GDP & $0.064^{* * *}$ & 0.005 & -0.008 & $-0.061^{* * *}$ & 0.028 \\
& {$[5.12]$} & {$[0.35]$} & {$[0.50]$} & {$[3.16]$} & {$[1.95]$} \\
Right-wing government & -0.01 & -0.023 & $0.165^{*}$ & $0.483^{* *}$ & $-0.151^{*}$ \\
& {$[0.14]$} & {$[0.50]$} & {$[1.71]$} & {$[2.59]$} & {$[2.04]$} \\
Election year & $0.086^{* *}$ & 0.022 & -0.117 & $-0.089^{*}$ & 0.04 \\
& {$[2.28]$} & {$[0.82]$} & {$[0.83]$} & {$[2.01]$} & {$[1.76]$} \\
Congress closed & $-0.266^{* *}$ & $-0.222^{* * *}$ & $-0.577^{* * *}$ & & \\
& {$[2.51]$} & {$[2.64]$} & {$[3.41]$} & & \\
Parliamentary regime & 0.23 & $-0.221^{* * *}$ & & & \\
& {$[1.49]$} & {$[2.67]$} & & & \\
Trend & $0.025^{* * *}$ & 0.011 & $-0.021^{*}$ & -0.031 & 0.004 \\
& {$[6.76]$} & {$[1.58]$} & {$[1.83]$} & {$[1.43]$} & {$[0.66]$} \\
Constant & $10.421^{* * *}$ & $1.918^{*}$ & 1.82 & $10.749^{* *}$ & -1.957 \\
& {$[11.16]$} & {$[1.83]$} & {$[0.64]$} & {$[2.36]$} & {$[1.53]$} \\
\hline Observations & 126 & 126 & 73 & 35 & 14 \\
\hline
\end{tabular}

$\mathrm{t}$ statistics in brackets (Newey-West standard errors).

$*$ significant at $10 \%$; * significant at $5 \%$; *** significant at $1 \%$. 
Housing expenditure shows positive impact of birth rates and a negative impact of death rates. As this good can be considered the best representation of a general good, an increase in total population (more births and less death) is expected to increase expenditure on housing.

Birth and death rates show positive (but not significant) effects on pension expenditure. The coefficient of birth rate is expected, since pensions are a good primarily consumed by elderly people: birth rates today do not affect elderly population. On the other hand, the impact of death rate is expected to be negative, assuming that a larger proportion of the deaths come from elders. Including life expectancy in the estimation does not change the results, but these are estimated with too few observations to get conclusive results.

Social expenditure is expected to be an important determinant of the expenditures of different goods, since it determines the total availability of resources. The result is confirmed for all the estimations, with coefficient positives and close to one.

The coefficient for the ratio fiscal income to GDP is positive for total expenditure and negative for house expenditure. The variable fluctuates constantly over the sample period, which explains the null effect on most estimations. The negative effect on housing is attributed to the change in the growing trend exhibited by the variable since 1850 as shown in Figure 9: the period of higher fiscal expenditure as percentage of GDP (1975-1989) matches the period of decrease in housing expenditure.

\section{FIGURE 9}

FISCAL INCOME/GDP AND HOUSE EXPENDITURE

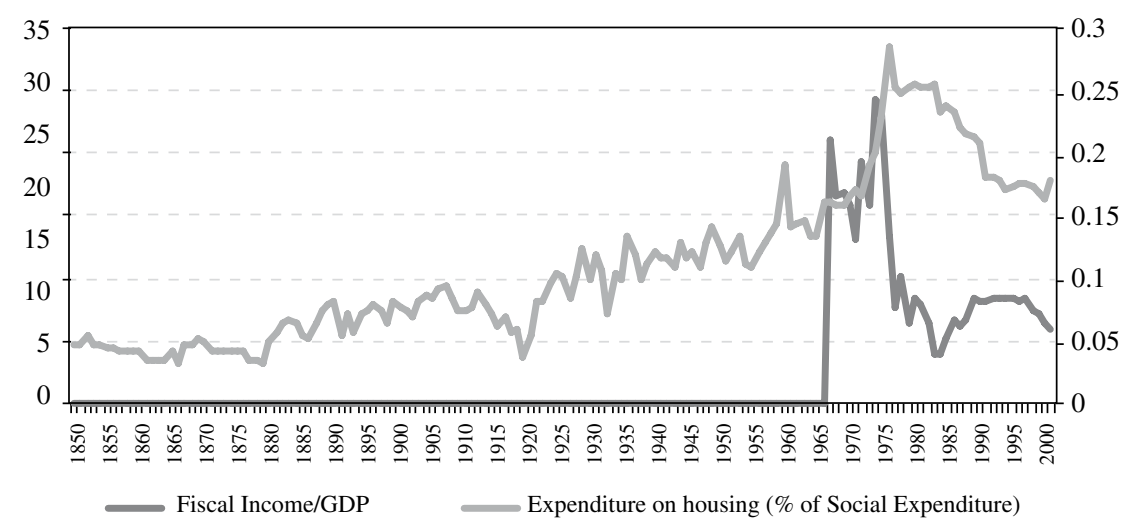

Source: Author's elaboration based on Díaz, Lüders and Wagner (2010). 
The political variables show no effect, except for the variable measuring political ideology, which reflects a higher propensity of right-wing government to spend in health and housing, and negative propensity to spend in pension. The first effects are hard to explain, since most of increases in the relative importance of the health expenditure came from non-right-wing governments (Ibáñez del Campo in the late 1920s and González Videla in the early 1950s). The same comment applies for the house expenditure, since the higher expenditure was done during left-wing governments (Allende in the 1970s and Concertación governments post 1990). On the other hand, although there is growing level of expenditure in pensions, it decreases in the late 1980s and then rise since 1990, explaining the negative impact of the variable in pensions. Election years seem to increase total expenditure, but have no effect in the other estimations (negative for housing expenditure).

The periods with no Congress seems to impact negatively total expenditure, as well as expenditure in education and health. In both cases, important reductions are observed in period in which the Congress was closed (1891, 1932 and 1973-1978) (see Figure 10).

FIGURE 10

\section{EDUCATION AND HEALTH EXPENDITURE, AND YEARS WITH CONGRESS CLOSED}

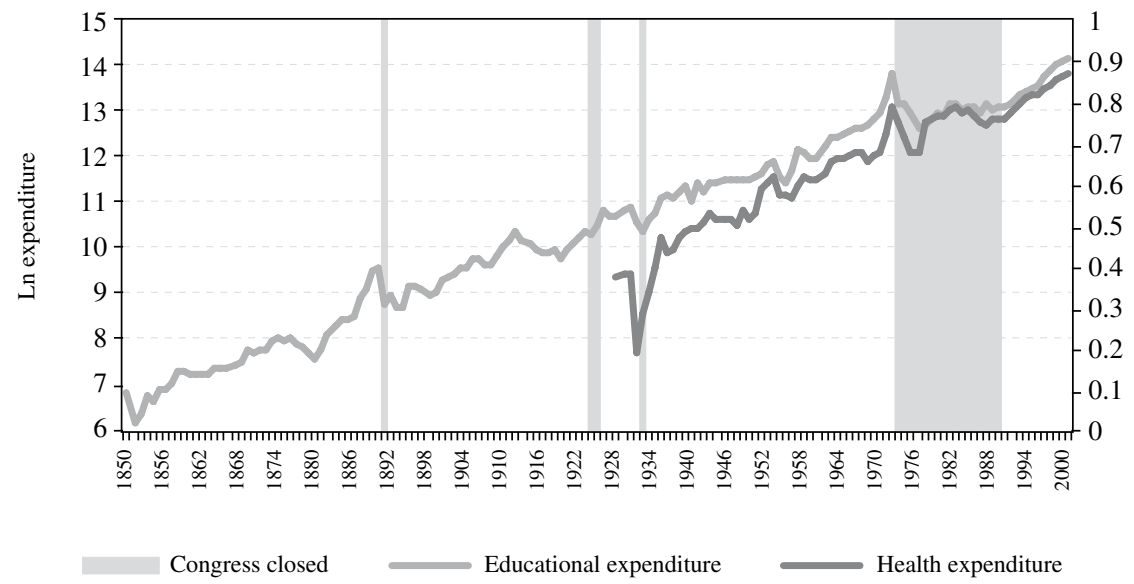

Source: Author's elaboration based on Díaz, Lüders and Wagner (2010).

The results hold when changing the specification (using linear-linear or log-log specifications). In order to deal with possible endogeneity problems, particularly relevant for health regressions, the same equations where estimated including GDP per capita as right-hand variable, obtaining similar results. 
Finally, in order to evaluate Result 3 (effect of changes in specific population on specific goods), it is necessary to look at the behavior of the expenditure in a specific good for periods of time when that specific population grew proportionally more than the others. The only variable for which this analysis is possible is expenditure on education: housing is considered a general good, while health -though can be viewed as specific good-cannot be attributed to a single age group. Social security expenditure is also a specific good, but the data does not contain a period of time where an increase in old population can be observed (data on pensions covers the period 1987-2000). This phenomenon - the third phase of demographic transition- is just starting in Chile, and still requires many years in order to be evaluated.

The sample is split into two periods. The first period (1911-1961) is a time when young population growth was relatively high compared to the rest of the population; during the second period (1962-2000), the young population continued growing but at a lower rate than other age groups (see Figure 7). As before, the variables in the estimation cointegrate (residuals are $I(0)$ ). These results are presented in Table 5 .

\section{TABLE 5}

IMPACT OF POPULATION ON EDUCATION EXPENDITURES, 1911-1961 AND 1962-2000

\begin{tabular}{|c|c|c|c|c|}
\hline Variables & $\begin{array}{c}(1) \\
1911-1961\end{array}$ & $\begin{array}{c}(2) \\
1962-2000\end{array}$ & $\begin{array}{c}(3) \\
1911-1961\end{array}$ & $\begin{array}{c}(4) \\
1962-2000\end{array}$ \\
\hline Birth rate & $\begin{array}{c}0.008 * * \\
{[2.30]}\end{array}$ & $\begin{array}{r}-0.001 \\
{[0.02]}\end{array}$ & $\begin{array}{c}0.008 * * * \\
{[2.93]}\end{array}$ & $\begin{array}{c}0.014 \\
{[0.26]}\end{array}$ \\
\hline Birth rate (lag 25) & $\begin{array}{l}-0.007 \\
{[1.55]}\end{array}$ & $\begin{array}{c}-0.035^{*} \\
{[1.84]}\end{array}$ & $\begin{array}{c}-0.008^{* *} \\
{[2.24]}\end{array}$ & $\begin{array}{c}-0.055^{* * * *} \\
{[3.81]}\end{array}$ \\
\hline Death rate & $\begin{array}{c}0 \\
{[0.00]}\end{array}$ & $\begin{array}{l}0.068 \\
{[0.39]}\end{array}$ & $\begin{array}{l}0.001 \\
{[0.15]}\end{array}$ & $\begin{array}{l}-0.031 \\
{[0.18]}\end{array}$ \\
\hline Social expenditure & $\begin{array}{c}0.850 * * * \\
{[11.27]}\end{array}$ & $\begin{array}{c}0.42 \\
{[1.61]}\end{array}$ & $\begin{array}{c}0.834 * * * \\
{[16.16]}\end{array}$ & $\begin{array}{c}0.422 * * * \\
{[3.25]}\end{array}$ \\
\hline Fiscal Income/GDP & $\begin{array}{l}0.003 \\
{[0.54]}\end{array}$ & $\begin{array}{c}-0.013 \\
{[0.64]}\end{array}$ & & \\
\hline Right-wing government & $\begin{array}{c}-0.004 \\
{[0.20]}\end{array}$ & $\begin{array}{c}-0.362 \\
{[1.17]}\end{array}$ & & \\
\hline Election year & $\begin{array}{l}0.026 \\
{[1.65]}\end{array}$ & $\begin{array}{l}0.047 \\
{[1.05]}\end{array}$ & $\begin{array}{l}0.028^{*} \\
{[1.79]}\end{array}$ & $\begin{array}{l}0.057 \\
{[1.07]}\end{array}$ \\
\hline Congress closed & $\begin{array}{l}0.032 \\
{[1.00]}\end{array}$ & $\begin{array}{l}0.314 \\
{[0.89]}\end{array}$ & & \\
\hline Parliamentary regime & $\begin{array}{l}0.071^{*} \\
{[1.93]}\end{array}$ & $\begin{array}{l}0.054 \\
{[1.53]}\end{array}$ & & \\
\hline Trend & $\begin{array}{c}-0.001 \\
{[0.77]}\end{array}$ & $\begin{array}{l}0.009 \\
{[0.34]}\end{array}$ & & \\
\hline Constant & $\begin{array}{l}1.519 \\
{[1.62]}\end{array}$ & $\begin{array}{l}6.504 \\
{[1.45]}\end{array}$ & $\begin{array}{l}1.554^{*} \\
{[1.89]}\end{array}$ & $\begin{array}{c}8.709 * * * * \\
{[3.89]}\end{array}$ \\
\hline Observations & 51 & 39 & 51 & 39 \\
\hline
\end{tabular}

t statistics in brackets (Newey-West standard errors).

$*$ significant at $10 \%$; ** significant at 5\%; *** significant at $1 \%$. 
Result 3 states that government expenditure on specific goods will be higher when the population consuming that good increases. In this case, birth rate, an important determinant of young population, has a positive effect on education expenditure in the period when the young population was growing at a faster rate (columns 1 and 3 ), effect that vanishes for the period in which young population is relatively less important (columns 2 and 4). Table 5 also shows the negative effect of the adult population (measured by the lagged birth rate) in government expenditure (Result 2). Result 4 cannot be tested using this data, since the ideal candidate for this analysis, housing expenditure, shows no data for years previous to 1966.

A more parsimonious estimation (columns 3 and 4) show the same affects. Results are also robust to changes in the threshold (plus/minus 5 years).

\section{CONCLUSIONS}

Chile, as many other countries has experienced significant demographic changes over the past years. These changes influenced many spheres of society's life, changing the environment and incentives faced by different agents in the economy. The government has been greatly affected by these changes, responding with the implementation of different policies throughout the years.

This paper suggests the existence of a link through which demographic characteristics, specifically the distribution of ages in the population, affects government's decisions. The effects of demographic transition on fiscal policies were assessed using a framework where the government acts as complement to the private sector in the provision of certain goods. The model highlights not only the relevance of the changing demands from diverse segments of the population, but the importance of the private sector in determining government's expenditure.

The empirical results support the conclusions suggested by the model. Particularly, it is found a negative effect of the adult population in the public expenditure and a positive impact of the expenditure in specific goods when the population demanding the good is relatively more abundant.

The lack of data makes difficult to extend the analysis any further. Especially interesting is the case of the expenditure in social security and the recent evolution started by the elderly population in Chile. To assess this factor in the future, it will be necessary to collect more information in order to evaluate these changes in a proper way.

\section{REFERENCES}

AGUILA, A. and H. MUÑOZ (1997). "Tendencia de la natalidad, mortalidad general, infantil y neonatal en Chile desde 1850 a la fecha", Revista Médica de Chile 125, pp. 1236-1245.

ALESINA, A. and E. SPOLAORE (2003). The Size of Nations, MIT Press, Cambridge, MA.

ALESINA, A. and G. TABELLINI (2007). "Bureaucrats or Politicians? Part I: A Single Policy Task", American Economic Review 97 (1), pp. 169-179.

ALlENDE, S. (1939). La Realidad Médico-Social Chilena. Ministerio de Salubridad, Previsión y Asistencia Social, Santiago. Accessed 5 March, 2012, http://www.memoriachilena.cl/archivos2/ pdfs/MC0000543.pdf. 
BAIROCH, P. (1993). Economics and World History, University of Chicago Press, Chicago.

BARR, N. (1992). "Economic theory and the welfare state: A survey and interpretation", Journal of Economic Literature 12 (3), pp. 741-803.

BENABOU, R. (2000). "Unequal Societies: Income Distribution and the Social Contract", American Economic Review 90 (1), pp. 96-129.

BEN-PORATH, Y. (1976). "Fertility Response to Child Mortality: Micro Data from Israel", Journal of Political Economy 84 (4), pp. S163-S178.

BIRDSALL, N. (1988). "Economic Approaches to Population Growth", in H. Chenery and T. N. Srinivasan (Eds.). Handbook of Development Economics, Vol. 1, Elsevier, Amsterdam, pp. 477-542.

BLOMQUIST, S. and V. CHRISTIANSEN (1999). "The political economy of publicly provided private goods", Journal of Public Economics 73, pp. 31-54.

BONGAARTS, J. (1987). "Does family planning reduce infant mortality rates?", Population and Development Review 13, pp. 323-334.

CASTILLO, C. (2005). Determinantes Económicos de la Fecundidad de Corto Plazo en Chile, M.A. Dissertation, Pontificia Universidad Católica de Chile.

CAVIERES, E. (1999). "Salud Pública. Estrategias, Políticas Fiscales y Cambio Cultural en la Reducción de la Mortalidad. Valparaíso, 1920-1960", Cuadernos de Historia 19, pp. 195-224.

CERDA, R.A. (2006). ¿Dónde Están los Niños? Determinantes Socioeconómicos de la Tasa de Natalidad en Chile, Santiago, Centro de Políticas Públicas, Pontificia Universidad Católica de Chile.

CERDA, R.A. (2008). "Cambios Demográficos y sus Impactos en Chile”, Estudios Públicos 110.

CIGNO, A. and M. WERDING (2007). Children and Pensions, MIT Press, Cambridge, MA.

COALE, A.J. and E.M. HOOVER (1958). Population Growth and Economic Development in Low-Incomes Countries, Princeton University Press, Princeton.

DIAZ, J., R. LÜDERS and G. WAGNER (2010). "La República en Cifras", EH Clio Lab-Iniciativa Científica Milenio. URL: http://www.economia.puc.cl/cliolab.

DONOSO, E., J. CARVAJAL and A. DOMINGUEZ (2009). "Reducción de la fecundidad y envejecimiento de la población de mujeres en edad fértil: 1990-2004”, Revista Médica de Chile 137, pp. 766-773.

DOWNS, A. (1957). An Economic Theory of Democracy, Harper and Row, New York.

EASTERLIN, R.A. (1975). "An Economic Framework for Fertility Analysis", Studies in Family Planning 6 (3), pp. 54-63.

ECHEVARRIA, C.A. (1995). "On age distribution of population, government expenditure and fiscal federalism", Journal of Population Economics 8, pp. 301-313.

FELDSTEIN, M. (1975). "Wealth Neutrality and Local Choice in Public Education", American Economic Review 65 (1), pp. 75-89.

FREEDMAN, R. (1961). "The Sociology of Human Fertility: a Trend Report and Bibliography", Current Sociology 10 (2), pp. 35-68.

GAZMURI, C. (2011). "La clase media. Alessandri Palma, Ibáñez y la intervención militar de 1924-1925. El ruido de sables en el Senado", HEMICICLO Revista de Estudios Parlamentarios 2 (4).

HARUYAMA, T., M. ASHIYA and S. HAMORI (2007). Demographic Changes, Fiscal Policy and Economic Growth: Theory and Evidence, Discussion Paper Series $N^{\circ} 0712$, Graduate School of Economics, Kobe University.

HINDRICKS, J. and G.D. MYLES (2006). Intermediate Public Economics, MIT Press, Cambridge, MA.

ILLANES, M. A. (1993). En el nombre del pueblo, del estado y de la ciencia. Historia social de la salud pública, Chile 1890-1973, Colectivo Atención Primaria, Santiago.

ITO, T. and A.K. ROSE (Eds.) (2010). The Economic Consequences of Demographic Change in East Asia, University of Chicago Press, Chicago.

KAEMPFFER, A. and E. MEDINA (2006). "Mortalidad infantil reciente en Chile: Exitos y desafíos", Revista Chilena de Pediatría 77, pp. 492-500.

KALDOR, N. (1963). “Will Underdeveloped Countries Learn to Tax?”, Foreign Affairs 41 (2), pp. 410-419.

KAPPELER, A. (2008). Essays on the Institutional Determinants of Public Expenditure, PhD. Dissertation, Ludwig-Maximilians-Universität München.

KUZNETS, S. (1966). Modern economic growth: Rate, structure and spread, New Haven, Yale University Press. 
LARRAÑAGA, O. (2006). "Comportamientos Reproductivos y Fertilidad, 1960-2003", in J. S. Valenzuela, E. Tironi and T. Scully (Eds.). El Eslabón Perdido. Familia, Modernización y Bienestar en Chile, Taurus, Santiago, pp. 97-136.

LAVAL, E. (2003a). "El cólera en Chile (1886-1888)", Revista Chilena de Infectología 20, pp. 86-88.

LAVAL, E. (2003b). "Chile 1918: Las dos epidemias”, Revista Chilena de Infectología 20, pp. 133-135.

LEE, R. (2003). "The Demographic Transition: Three Centuries of Fundamental Change", Journal of Economic Literature 17 (4), pp. 167-190.

LEE, R., W.B. ARTHUR and G. RODGERS (1988). Economics of Changing Age Distributions in Developed Countries, Oxford University Press, New York.

LINDERT, P.H. (1996). "What Limits Social Spending?", Explorations in Economic History 33, pp. 1-34.

MACKINNON, J.G., H. WHITE and R. DAVIDSON (1983). "Tests for model specification in the presence of alternative hypotheses: Some further results", Journal of Econometrics 21, pp. 53-70.

MaCURDY, T. and T. NECHYBA (2001). "How Does a Community's Demographic Composition Alter Its Fiscal Burdens?", in A. J. Auerbach and R. D. Lee (Eds.). Demographic Change and Fiscal Policy, Cambridge University Press, Cambridge, pp. 101-148.

MALTHUS, T.R. (1798). An Essay on the Principle of Population, Dutton, New York.

MEDINA, E. and A. KAEMPFFER (2007). "Tendencias y características de la mortalidad chilena 19702000", Revista Médica de Chile 135, pp. 240-250.

MERRIFIELD, J. (2000). "State government expenditure determinants and tax revenue determinants revisited", Public Choice 102, pp. 25-50.

MINISTERIO DE HIJIENE, ASISTENCIA, PREVISIÓN SOCIAL I TRABAJO (1925). Recopilación oficial de leyes y decretos aprobados, Ministerio de Hijiene, Asistencia, Previsión Social i Trabajo, Santiago.

MOURAO, P.R. (2007). "Long-Term Determinants of Portuguese Public Expenditures", International Journal of Finance and Economics 7, pp. 153-167.

MURILLO, A. (1896). La Mortalidad Urbana en Chile. Discurso leído en la sesión de apertura del Congreso Científico General Chileno. Imprenta y Encuadernación Roma Santiago. Accessed January 15, 2013. http://www.memoriachilena.cl/archivos2/pdfs/MC0027487.pdf.

MUSGRAVE, R.A. (1959). The Theory of Public Finance, McGraw-Hill, New York.

OATES, W.E. (1972). Fiscal Federalism, Harcourt Brace Jovanovich, New York.

OHTAKE, F. and S. SANO (2010). "The Effects of Demographic Change on Public Education in Japan", in T. Ito and A. K. Rose (Eds.). The Economic Consequences of Demographic Change in East Asia, University of Chicago Press, Chicago, pp. 193-219.

PAINTER, G. and K. BAE (2001). "The Changing Determinants of State Expenditure in the United States: 1965-1992", Public Finance and Management 1 (4), pp. 370-392.

PERSSON, T. and G. TABELLINI (2000). Political Economics: Explaining Economic Policy, MIT Press, Cambridge, MA.

POTERBA, J.M. (1997). "Demographic Structure and the Political Economy of Public Education”, Journal of Policy Analysis and Management 16 (1), pp. 48-66.

POTERBA, J.M. (1998). "Demographic Change, Intergenerational Linkage, and Public Education", American Economic Review 88 (2), pp. 315-320.

POTRAFKE, N. (2008). Political effects on the allocation of public expenditures: Empirical evidence from OECD countries, Mimeo.

PRINCHETT, L. and M. WOOLCOCK (2008). "Solutions When the Solution Is the Problem: Arraying the Disarray in Development", in W. Easterly (Ed.). Reinventing Foreign Aid, MIT Press, Cambridge, MA, pp. 147-178.

RACZYNSKI, D. and C. OYARZO (1981). “Por qué cae la tasa de mortalidad infantil en Chile?”, Colección Estudios CIEPLAN 6, pp. 45-84.

SAN FRANCISCO, A. (2007). La Guerra Civil de 1891. Chile. Un país, dos ejércitos, miles de muertos (Tomo 2), Centro de Estudios Bicentenario, Santiago.

SANZ, I. and F.J. VELASQUEZ (2002). Determinants of the Composition of Government Expenditure by Functions, European Economy Group Working Paper $\mathrm{N}^{\circ} 13$.

SANZ, I. and F.J. VELASQUEZ (2007). "The role of ageing in the growth of government and social welfare spending in the OECD", European Journal of Political Economy 23, pp. 917-931.

SCHULTZ, T.P. (2010). "Population and Health Policies", in D. Rodrik and M. R. Rosenzweig (Eds.). Handbook of Development Economics, Vol. 5, Elsevier, Amsterdam, pp. 4785-4881. 
SCHUMPETER, J.A. (1918/1991). "The Crisis of the Tax State", in R. Swedberg (Ed.). The Economics and Sociology of Capitalism, Princeton University Press, Princeton, NJ, pp. 99-140.

SERVICIO NACIONAL DE SALUD (1967). "Política y Programa de Regulación de la Natalidad en el Servicio Nacional de Salud de Chile", Circular N ${ }^{\circ}$ 998, Dirección General.

SHI, M. and J. SVENSSON (2006). "Political budget cycles: Do they differ across countries and why?", Journal of Public Economics 90, pp. 1367-1389.

SZOT-MESA, J. (2003). "La Transición Demográfico-Epidemiológica en Chile, 1960-2001", Revista Española de Salud Pública 77, pp. 606-613.

TANZI, V. (1981). "A Statistical Evaluation of Taxation in Sub-Saharan Africa", IMF Occasional Paper 8.

TRIDIMAS, G. (2001). "The economics and politics of the structure of public expenditure", Public Choice 106, pp. 299-316. 


\section{APPENDIX 1: DERIVATION OF RESULTS}

Consider a typical economy composed by firms, households and government, where all these entities are integrated by persons. People in each group can differ in a series of characteristics, but we assume they are fully described by their age. In particular any person belongs to one of the following groups: young $(Y)$, adult $(A)$, or elderly $(E)$. Assume the typical scheme of the circular flow of the economy: needs from the households (goods and services) are satisfied by firms and government, while needs of firms and government (labor supply), are supplied by household.

In a population described by age profiles, it is possible to think of two types of goods: general and specific. General goods are demanded by every person, regardless his or her age. On the other hand, the demand for specific goods is idiosyncratic to each age group.

Firms and government produce general and specific goods, using labor supplied by adults, and changes in the output are only due to changes in the labor supply. Moreover, assume that the government acts as supplement of the private sector ${ }^{22}$, and that all markets are equally profitable for the private firms. In this case, the assumption of a benevolent government helps to explain why public expenditure is used to supplement the gap between demand and private supply; although different set ups of government behavior can lead to similar results ${ }^{23}$. Particularly, the median voter theorem can be used as framework to explain the causal relationship between demographic variables and public policy outcomes. The existence of different groups in the population with different preferences over policies, explains changes in government's priorities throughout the time: the demand for certain goods correlates directly with the relative importance determined groups in the population, which, on the other hand represent the pool of voters. It is assumed that politicians try to maximize their probability of victory in the elections, choosing policies before the election (Persson and Tabellini, 2000). As shown by the median voter models, a key assumption is the ability of the candidates and governments to commit to announced policies ${ }^{24}$. The main problem with this approach is that rules out the importance of the young population: they have specific demands, but no vote. To solve the paradox, it is necessary to include additional assumptions. It is usually assumed that voters (adults and elderly) are not

22 If we think in these general and specific markets as markets for basic or minimum needs -categorical equity goods (Feldstein, 1975)-, then the role of the government is clearer, because the demand must be satisfied. In the case of "regular" goods, it is arguable that the adjustments between demand and supply will be produced via changes in prices.

23 Alesina and Spolaore (2003) point out that rent-maximizing governments (Leviathans) can implement pro well-being policies even if they do not care about their subjects directly. Persson and Tabellini (2000) reach the same conclusion using a model based on democratic choices (median voter theory). Bénabou (2000) extends the median voter framework to an environment where wealth can influence the political outcome, while Haruyama, Ashiya and Hamori (2007) and Ohtake and Sano (2010) applied it to explain the effects of demographic transition in public expenditures.

24 This fact fits with the model by Alesina and Tabellini (2007) where politicians choose policies to win elections, and bureaucrats implement these policies while in power. 
completely selfish and myopic, and there exist a degree of preference over policies that favor another group. One possibility is to assume the existence of pure altruism. Alternatively, many authors stress the possibility of distributional policies under different schemes, like insurance for the future (Blomquist and Christiansen, 1999; Barr, 1992) or externalities (Poterba, 1997, 1998).

The economy described above can be modeled as follows. The total population in each period is the sum of the population in each age group:

$$
N=N_{Y}+N_{A}+N_{E}
$$

The aggregate demand for each good (general and specific) is a function of the population:

$$
\begin{aligned}
& X_{D}^{\text {General }}=g_{G}(N)=g_{G}\left(N_{Y}, N_{A}, N_{E}\right) \\
& X_{D}^{\text {Specific(i) }}=g_{S}\left(N_{i}\right) \quad \mathrm{i}=Y, A, E
\end{aligned}
$$

where $X_{D}^{\text {General }}$ is the demand for general goods and $X_{D}^{\text {Specific(i) }}$ is the demand for each specific good $i$, and g' $>0$.

The firms use only adult population to produce both types of goods. If labor is the only factor of production (or if other factors remain constant) and both type of goods use the same technology of production ${ }^{25}, f$, the firms' supply of goods can be expressed as:

$$
\begin{gathered}
X_{S, F}^{\text {General }}=f\left(N_{A}\right) \\
X_{S, F}^{\text {Specific }(i)}=f\left(N_{A}\right) \quad \mathrm{i}=Y, A, E
\end{gathered}
$$

where $X_{S, F}^{\text {General }}$ and $X_{S, F)}^{\text {Specific(i) }}$ are the firms' supply of general and specific goods, and $f^{\prime}>0$. If the government acts as complement of the private sector in the provision of goods, then the government's provision of goods ${ }^{26}$ in each period will be:

$$
\begin{gathered}
X_{S, G}^{\text {General }}=X_{D}^{\text {General }}-X_{S, F}^{\text {General }} \\
X_{S, G}^{\text {Specific(i) }}=X_{D}^{\text {Specific }(i)}-X_{S, F}^{\text {Specific }(i)} \quad \mathrm{i}=Y, A, E
\end{gathered}
$$

25 This assumption can be relaxed without changing the main conclusions of the model.

26 The use of the term "public good" to denote "goods publicly provided" is avoided. MaCurdy and Nechyba (2001) use fiscal expenditure as a synonym for public good expenditure. Echevarria's model (1995) supposes the cost of providing public goods as the only determinant of fiscal expenditure, although he explicitly includes a parameter to account for the "degree of publicness of the public good". 
where $X_{S, G}^{\text {General }}$ and $X_{S, G}^{\text {Specifif(i) }}$ represent the government provision of general and specific goods. If markets clear, the total supply will be every period equal to the demand in each market:

$$
X_{S}=X_{S, F}+X_{S, G}=X_{D}
$$

Assuming a cost of production equal to $\mathrm{c}$, then the government expenditure will be:

$$
G=c\left(X_{D}-X_{S, F}\right)
$$

Letting the cost of production of each good be different:

$$
\begin{gathered}
G^{\text {General }}=c^{\text {General }}\left(X_{D}^{\text {General }}\left(N_{Y}, N_{A}, N_{E}\right)-X_{S, F}^{\text {General }}\left(N_{A}\right)\right) \\
G^{\text {Specific }(i)}=c^{\text {Specific }(i)}\left(X_{D}^{\text {Specific }(i)}\left(N_{i}\right)-X_{S, F}^{\text {Specific }(i)}\left(N_{i}\right)\right)
\end{gathered}
$$

\begin{tabular}{|c|c|c|c|c|}
\hline & $\partial G^{\text {General }}$ & $\partial G^{\operatorname{Specific}(Y)}$ & $\partial G^{\text {Specific(A) }}$ & $\partial G^{\text {Specific(E) }}$ \\
\hline$\partial N_{Y}$ & $c^{\text {General }}\left(\frac{\partial g_{G}}{\partial N_{y}}\right)$ & $c^{(Y)}\left(\frac{\partial g_{S}}{\partial N_{Y}}\right)$ & 0 & 0 \\
\hline$\partial N_{A}$ & $c^{\text {General }}\left(\frac{\partial g_{G}}{\partial N_{A}}-\frac{\partial f}{\partial N_{A}}\right)$ & $c^{(Y)}\left(-\frac{\partial f}{\partial N_{A}}\right)$ & $c^{(A)}\left(\frac{\partial g_{S}}{\partial N_{A}}-\frac{\partial f}{\partial N_{A}}\right)$ & $c^{(E)}\left(-\frac{\partial f}{\partial N_{A}}\right)$ \\
\hline$\partial N_{E}$ & $c^{\text {General }}\left(\frac{\partial g_{G}}{\partial N_{E}}\right)$ & 0 & 0 & $c^{(E)}\left(\frac{\partial g_{S}}{\partial N_{E}}\right)$ \\
\hline$\partial N$ & $c^{\text {General }}\left(\frac{\partial g_{G}}{\partial N}-\frac{\partial f}{\partial N_{A}}\right)$ & $c^{(Y)}\left(\frac{\partial g_{S}}{\partial N}-\frac{\partial f}{\partial N_{A}}\right)$ & $c^{(A)}\left(\frac{\partial g_{s}}{\partial N}-\frac{\partial f}{\partial N_{A}}\right)$ & $c^{(E)}\left(\frac{\partial g_{S}}{\partial N}-\frac{\partial f}{\partial N_{A}}\right.$ \\
\hline
\end{tabular}

The response of the government expenditure to changes in population can be measured deriving equations (A.10) and (A.11) with respect to every $N_{i}$ :

IMPACTS OF POPULATION CHANGES ON GOVERNMENT EXPENDITURE

Each row shows the effect of the change in population for the different age groups on each type of good. The last row summarizes the total effect of changes in population, regardless of its age. The basic results from the table and equations A.10 and A.11 are: 
Result 1: Changes in total population (fourth row) have uncertain impact on government expenditure. The impact will depend on the effect of the population on the demand for general goods $\left(\frac{\partial g_{G}}{\partial_{N}}\right)$ and specific goods $\left(\frac{\partial g_{S}}{\partial N}\right)$, with respect to the change in private labor supply producing those goods $\left(\frac{\partial f}{\partial N_{A}}\right)$.

Result 2: Changes in adult population (second row) impact negatively government expenditure in specific goods consumed by the other groups $\left(-\frac{\partial f}{\partial N_{A}}\right)$, i.e. young and elderly, and have uncertain effects in adult specific goods and general goods $\left(\frac{\partial g}{\partial N_{A}}-\frac{\partial f}{\partial N_{A}}\right)^{27}$.

Result 3: In the case of specific goods (columns 2 and 4), changes in population affect positively fiscal expenditure on goods consumed by the group that increased its population $\left(\frac{\partial g_{S}}{\partial N_{i}}\right)$.

Result 4: Fiscal expenditure on general goods (column 1) reacts positively to changes in young or elderly population $\left(\frac{\partial g_{G}}{\partial N_{i}}\right)$.

Additionally, it is necessary to add the government's budget constrain. With this additional restriction, (A.9) can be written as:

$$
G=c\left(X_{D}-X_{S, F}\right), \text { subject to } G \leq I
$$

where I is the government's income.

The model predicts the effects of changes in different populations over a set of goods. Notwithstanding its shortfalls, the model presents in a simple way the interaction between public and private sector to determine the provision of "fundamental" goods.

27 Here it is necessary to add an additional caveat. Adult population affects the private and public supply of goods, since both use it as input in their production functions. Equations A.6 and A.7 capture the impact of adult population on government supply only indirectly through the changes in private supply. The explicit inclusion of adult population in the public supply of categorical equity goods does not affect the main results, but reinforce them: a reduction in $N_{A}$ decreases the private supply of goods (or increase their private cost of production). Since the government "must" provide the excess of demand, the increase in government expenditure is explained by the bigger production $\left(X_{D}-X_{S, F}\right)$ "and" the increase in cost of production $(c)$ due to the scarcity of labor. Similarly, an increase in adult population reduces the excess of demand "and" the cost of production. 
Unlike other models, it explicitly accounts for the changes in labor force as a driven factor behind the determination of the public expenditures and permits to expand the role of the government beyond the provision of pure public goods.

\section{APPENDIX 2: DEFINITION OF VARIABLES}

\begin{tabular}{|lll|}
\hline Variable & \multicolumn{1}{c|}{ Definition } \\
\hline Young population (\%) & \multicolumn{2}{l|}{ Population between 0 and 19 years/total population } \\
Adult population (\%) & \multicolumn{2}{l}{ Population between 20 and 69 years/total population } \\
Elderly population (\%) & \multicolumn{2}{l}{ Population over 80 years/total population } \\
Total fiscal expenditure & 1) & General: government, defense, justice and security \\
& 2) & Social: health, housing, social security, education, subsidies, and others \\
& 3) & Economic: promotion and regulation of productive activities, and infrastructure \\
& 4) & Other non-classifiable \\
Health expenditure & 5) & Public Debt Interests \\
Housing expenditure & 1) & Ministry of Health; 2) Other \\
Education expenditure & 1) & Ministry of Housing; 2) Other \\
Social security expenditure & 1) & Ministry of Education; 2) Other \\
& 1) & Pension Fund, INP, and FNPA \\
& 2) & Undersecretary of Social Welfare \\
& 3) & Superintendency of Social Security \\
& 4) & Superintendency of Pension Funds \\
Other social expenditure & 5) & Fiscal pensions \\
& 1) & Ministry of Labor \\
& 2) & Social Fund and Subsidies \\
& 3) & Other institutions \\
\hline
\end{tabular}

